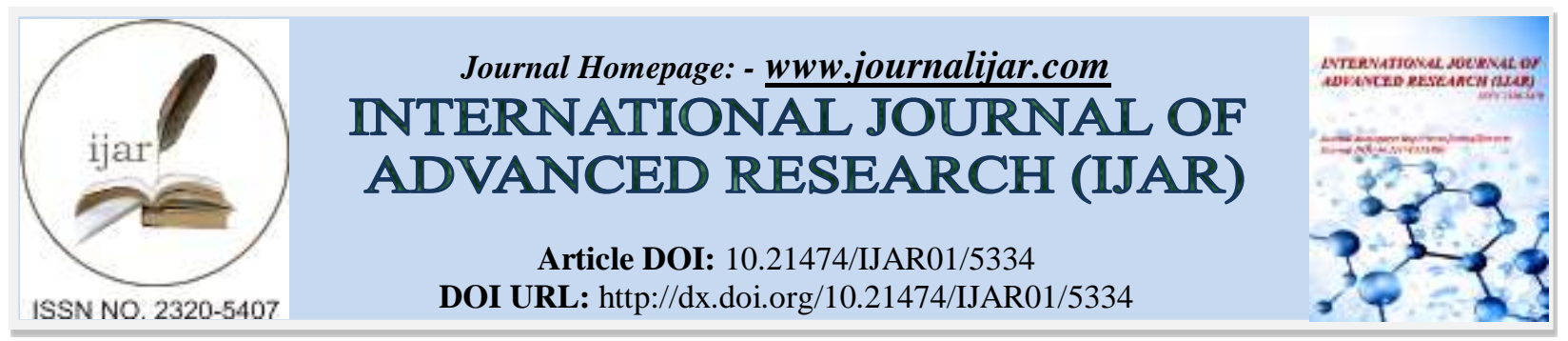

RESEARCH ARTICLE

\title{
IMPACT OF RACISM ON IDENTITY AND SOCIAL IN RICHARD WRIGHT'S NATIVE SON AND BLACK BOY.
}

\section{Mutaz Tarik Shakir ${ }^{1}$ And Dr. G.Chenna Reddy ${ }^{2}$.}

1. Research Scholar (PhD),Department of English, Acharya Nagarjuna University, Nagarjuna Nagar, AP, India.

2. Assistant Professor and Research Director, Department of English, Acharya Nagarjuna University, Nagarjuna Nagar, AP, India.

\section{Manuscript Info}

Manuscript History

Received: 05 July 2017

Final Accepted: 07 August 2017

Published: September 2017

Key words:-

Racism, fear and shame, social and racial identity, racial injustice.

\begin{abstract}
The current article focuses on the investigation of the theme of social and racial identity of the African American characters in the fictional works of Richard Wright's Native Son (1940) and autobiography Black Boy (1945) created a controversial world shocking the sensibilities of both Black and White America by presenting the cultural and social realities behind racism that has been a matter of question in the United States for centuries. In the social climate characterized by racial conflicts and psychic tension specific to the previously mentioned period, the identity formation process of the Negroes is a highly debatable and a never ending one. Therefore numerous literary exemplifications from Richard Wright's novels and short stories will be offered, including Wright's self-referential account that also illustrates the tragedy of an author held captive in a hostile world. Thus, this study aimed to discuss how the racial stereotypical picture held in both groups' mind became destructive and double-edged racism by focusing on racism on identity, social and cultural conflicts of racism in Wright's Native Son and in Black Boy.
\end{abstract}

Copy Right, IJAR, 2017,. All rights reserved.

\section{Introduction:-}

Among the African American writers Richard Wright came into prominence, with his creative expression concerned with the social complexities of the Unites States and the reality of African Americans as oppressed minority. Wright wrote his reactions against the inadequacies of blacks in the American society. His writings gave a turning point to the cultural explosion of African American literature. It paved the way for new theories with the significant support of Harlem Renaissance, where the interest of many black intellectuals were patronized for the up liftmen of artists and for the effective social reforms. Richard Wright was a pioneer in American Literature whose relationship with socialism helped to define him as a person and as a writer. The inspiration behind his literary accomplishments and their impact on his contemporaries can be understood by tracing two of the most important themes in his life; socialism and identity.

Richard Wright's influence on American literature was profound. His popular writings Native Son (1940) and Black Boy (1945) were a commercial as well as a critical success. Black Boy was a great success and is still considered Wright's masterpiece by many critics. The critic Irving Howe said:

Corresponding Author:- Mutaz tarik shakir.

Address:- Research Scholar (PhD),Department of English, Acharya Nagarjuna University, Nagarjuna Nagar, AP, India. 
"The day Native Son appeared, American culture was changed forever. No matter how much qualifying the book might later need, it made impossible a repetition of the old lies. In all its crudeness, melodrama, and claustrophobia of vision, Richard Wright's novel brought out into the open, as no one ever had before, the hatred, fear, and violence that have crippled and may yet destroy our culture.”(Page,2011,p.323)

Richard Wright's contributions to American literature were perhaps best summed up by Dan McCall, professor of American studies at Cornell University, in his 1969 book, The Example of Richard Wright:

Wright is the father of the contemporary black writer because when we come to Wright's best work we are faced with the central question about being black in America. Richard Wright was the first man to put it to us with all its naked power...the farther we get from Richard Wright and his modes of thought, the better we can see the extent of the debt we owe him...However outmoded some of his weapons may seem now, Richard Wright was the man who first conquered the big ground... The achievement of Richard Wright came from his determined ability to explore his own individual suffering and create from it crucial examples of what "all the long centuries" mean.

Wright's attack on racism, including the racism of the judicial system, becomes substantially more detailed. Some readers feel Wright has already made that case quite well earlier. However, because he focused so heavily on the horrors of Bigger's crimes in the first two books, he may now need to remind readers of the horrors of the societ y that Bigger thought he was attacking. Wright seems to be continuing his indictment of racism and of the criminal justice system. The preoccupations of Black Boy with racism and with Wright's development as a writer merge identified in chapter eight. (Gallantz, 1985,p.70)

Richard is attracted to Mencken because a newspaper that usually attacks black people has attacked Mencken. In reading Mencken, his desire to fight back against whites and his desire to write stories fuse for what appears to be the first time. But, of course, as you may have already noticed, words and rebellion have been connected before at least as early as the day he wrote obscenities on his neighbors' windows. Richard reads Sinclair Lewis, Theodore Dreiser, and some of the other authors Mencken discusses. He develops a passion for reading, but he worries that his reading will antagonize the whites around him. Whites think that reading makes blacks rebellious.( Gómez, J.D.2015, 33-43). Henry Louis Gates, Jr., has called America a "fundamentally racist society" (Cheney, 1991) and in his novel Native Son (1940), Richard Wright shows the workings of such a society at the level of personal interaction. Dealing with the concept of "black identity" in Richard Wright's fiction involves a complex approach to a whole network of critical perspectives and fictional representations of institutionalized inequality, intolerance and violence at the crossroads of the various cultural discourses that marked important developments in $20^{\text {th }}$ century America.

The main objective of this study is to examine and comparing the two works of Richard Wright, on racism on black identity, suppression, oppression and social, the major predicaments of blacks in the matrix of inter and intra continental and racial setup.

\section{Discussion:-}

Bigger has no discernible association to himself, to his own life, to his own people, nor to any, other people- in this respect, imaginably, he is most American- and his force comes not from his significance as a social (or anti-social) unit, but from his significance as the incarnation of a myth. It is remarkable that, though we follow him step by step from the tenement room to the death cell, we know as little about him when this journey is ended as we did when it began; and, what is even more remarkable, we know almost as little about the social dynamic which we are to believe created him. The Rumanian critic Lucien Goldmann is concerned to examine the structure of a literary text for the degree to which it embodies the structure of thought of the social class or group to which the writer belongs. Having writing Native Son does not come from nothingness. It comes as a reflection of the society the author was lived in, a black society in which Richard Wright experienced and which affected him to create this great knowledgeable novel.

\section{"Native Son":-}

In the story of Native Son, Thomas's lawyer pleads for mercy on the grounds that his client had become the oppressed victim of social conditioning and white racism, but the plea for mercy was to no avail. Under Wright's pen, Bigger Thomas comes to a vivid awareness of his identity as a black man in a white world, as when he says, "I didn't know I was really alive in this world until I felt things hard enough to kill for 'em." The central character in 
Native Son is indeed a native son, a product, of the United States, but not one for who many one wants to take responsibility. Three centuries of slavery, oppression, and racism have resulted in the creation of a young black man who is intimidated by whites to such a degree that he accidentally smothers a white woman just so he will not be discovered in her bedroom, which would mean only one thing, rape, as it is a given in his society that a white woman would never voluntarily have sex with a black man. He soon afterward murders a young black woman, his own girlfriend no less, in an extremely brutal manner. He is not, to summarize, a man for whom even bankers' daughters would shed tears, as Wright feared had happened upon the publication of his Uncle Tom's Children two years before Native Son appeared in 1940.

In Richard Wright's fiction the African Americans are treated as inanimate objects and are forbidden any possibility of human manifestations. Quite obviously, this fact results in the annulment of the personal and social dimension of their self and implicitly in a split self and an identity crisis. Bigger Thomas, the main character of Native Son, represents the most convincing example of the split self in Richard Wright's fiction. His case is not an unusual one in terms of external perception, human interaction or social identity. It may well be argued that Bigger Thomas' humanity is not a matter of concern for white people. Just like all the black characters from Wright's prose, he is considered to be an inferior human being and therefore he is not allowed to socially interact with members of white society. This results in a total failure of the process of the identity formation, which eventually leads to a split self and implicitly, to an identity crisis. Quite significantly, the identity crises spans almost a life time, since he never actually succeeds in becoming a real human being.

Richard Wright's realistic novels Native Son and Black Boy achieved in classifying the multi-facets of socialtragedy. His works inter-related the race, the impact of slavery, the politics of prejudice, racism, and examined the understanding of African-American, and depicted the individual behavior, and the social struggle. The society crippled them in every respect. As the story has a complex plot, Richard reveals the anxiety of the father and at the same time links the society to demonstrate the vulnerability that drags them to social anomalies. The use of colloquial language is a way of application where Richard tries to inter-relate the circumstances and reality

Many readers of all colors and political views still find Native Son and Black Boy compelling indictments of racism and penetrating character studies of individuals in revolt. Native Son is an indictment of racism. Racism affects Bigger's life at home, at the Daltons, and in police custody. The Thomas's must live in their rat-infested apartment partly because no one will rent to blacks in any other section of town. At the same time, blacks are charged higher rents than whites. When Bigger goes to the movies, one of the films portrays blacks as jungle savages. After his arrest, Bigger finds that the press and the public are using racial stereotypes to portray him as a sex criminal and brutal mass murderer. And despite their best intentions, even the liberal Daltons and the radical Jan and Mary act toward Bigger in a racist manner by failing to recognize him as an individual .' Gallantz, 1985,p.26)

In Native Son it is the denial of identity and alienation that young black men (to say nothing of the women who are almost always worse off) face that precipitates tragedy. Wright saw this sense of exclusion as a threat to them and to anyone else who chanced to be near. Bigger Thomas, like the author, is seldom perceived as a whole person. Throughout the novel he is quartered and objectified by the whites in power and responds by alternating between periods of dejected impotence and rage. Wright explains Bigger's alienation through the prism of dialectical materialism so that the novel's social protest is founded on the socialist theoretical constructs with which Wright was familiar.

Once Bigger is arrested he says nothing, even after learning that Bessie's body has been found. However, when Buckley begins to explain the crimes of rape and murder with which he is charged, Bigger protests, vigorously denying rape and Jan's part in Mary's death. Under a steady fire of questions, Bigger breaks down and signs a confession. Soon Jan testifies. Knowing Jan is a Communist, the prosecutor performs a cross-examination not only about Jan's knowledge of Bigger but about Jan's beliefs about the cultural logic of racism:

Do you believe in social equality for Negroes?' 'I believe all races are equal, 'Jan began. 'Answer yes or no Mr. Erlone! You are not on a soap box.' 'Do you believe in social equality for Negroes?' 'Yes.' 'Did you shake hands with that Negro?' 'Yes.' 'How many times have you eaten with Negroes before?' 'I do not know. Many times.' You like Negroes?' 'I make no distinctions' (Native son, 1940). 
This questioning of the prosecutor is a condemnation of crossing racial boundaries as much as it is an investigation of Bigger. It shows race prejudice by indicting Jan simply for crossing over normally accepted boundaries of space between white and black society, for treating a black man as a human being.

On psychological, sociological and cultural levels, either directly or indirectly, both whites and blacks are responsible of the prejudice racist views and negative stereotypical images unconsciously drawn by both groups due to lack of communication, boundaries and fear. Bigger dramatizes the anger and pain of his race regarding "fearhate-fear complex", and the Daltons effectively represent the ruling white power structure regarding "guilt-hate-fear complex". Thus, to be black in America means to be the victim of social values and race prejudice. Bigger Thomas's fear, flight, fate and trial dramatize American racism, its pervasiveness, and the way racism prevents social and cultural understanding or compassion for the other. Oppressors rule by force and are corrupted; victims are blind and intimidated, and are corrupted. Shortly before his death, Bigger begins to see Jan as an individual, not as a white man, but it is too late. In its exploration of America's logic of racism the novel shows that Bigger Thomas ultimately cannot escape that logic that has been unconsciously shaped starting from childhood by elders. Native Son inverts the common American assumption of individual opportunity. Both Bigger's crimes and his fate merely fulfil society's expectations of him as a black man and the Dalton's attitudes fulfil the society's expectation of a white but both Bigger and Daltons are directly victims and indirectly criminals of each other because of their cultural logic of racism that makes them act in a blind and prejudice attitude ( Meryem Ayan, pp. 135-139)

This study shades light on racism of the twentieth century Richard Wright's Native Son. Nervous, fear, and hate, expressed by Wright's protagonist, Thomas Bigger, comes from his society. The novel structured the American society in which both black and white suffer.

\section{"Black Boy":-}

With the suggestion of his publishers Wright turned to autobiography. Black Boy, an account of the author's first seventeen years, was another critical success for Wright, but embittered by the racist materialism of American society and fortified by a journey to Europe in 1946, Wright left the United States and established permanent residence in France in 1947.

Wright's 'Black Boy' which was the semi-autobiography of Wright described his early life and he reveals the clashes with his Seventh Day Adventist family. Moreover he explains his troubles with white employers and social isolation.

The insidious effects of racism are the main themes of this autobiography. 'Black Boy' however discovers racism not only as a loathsome belief held by odious persons but also sinister problem join into the very fabric of society as entire. Wright describes characters such as Olin and Pease as evil public, but also and more alarmingly - as bit players in a vast drama of odium, fear and coercion. For Richard, the real problem of racism is not simply that it exists, but that it roots in American nation are so deep it is unsure whether these roots can be demolished without destroying the culture itself. More than just an autobiography Black Boy symbolizes the culminations of Wrights fervent desire to observe and intimate upon the racist world around him. All over the work we see Richard observe the harmful effects of racisms not only as it affects dealings between whites and blacks, but also dealings among blacks themselves. Wright enables his work Black Boy primarily stress on the word "black" the story of childhood, but at every moment booklovers are actually aware of the colour of Wright's skin.(Pallavi T. Ramteke, 2013, pp 6877)

Wright was able to carve out such a large piece of the U.S. autobiographical tradition for himself and his life because Black Boy is so intensely realized and vivid, especially in Part One. Against irrational but nearly overwhelming power, the hero maintains his integrity and imagination through his determination and persistence. In other words, Black Boy is a very American story of a young man's confrontation with a hostile environment, which threatens annihilation if he does not submit to it. But Wright constantly defies the world around him in order to maintain his self-respect and to become the author of Black Boy. A system that was designed to crush Wright ironically produced one of its most powerful critics as well as one of the most powerful voices in twentieth-century U.S. literature. In particular, writing helped Wright explore the issue of race, another significant idea in Black Boy. That racism is an effect of ignorance on the part of whites is one of the points the book drives home over and over. 
Black Boy attacks the racism of the South during the period Wright was budding up there (1908-1927). Many of the sufferings of Wright's family life are direct or indirect results of racial acumen. Once Wright enters the world of work, he finds racism universal and unbearable. The book determines with Wright's fleeing the South and the racist environments he has been forced to sustain there (Spark Notes,2003). In Black Boy, A Record of Childhood and Youth, the author portrays the climax of white ferocity against black people. The "black boy" is compelled to learn facts about life in a climate of terror, fear, hunger, hatred and violence that goes his life into a chilling:

"My sustained expectation of violence had exhausted me. My preoccupation with curbing my impulses, my speech, my movements, my manner, my expressions had increased my anxiety". (wright 1998, p.197)

In addition to assumptions governing Wright's attitudes toward race and social class, there are gender-based suppositions that can be detected throughout Black Boy. It seems odd, for instance, for Wright to refer to his adult Aunt Jody as a "girl" (Black Boy,104), and it is embarrassing to read that Granny and Aunt Addie became so hostile toward him that they ordered him to wash and iron his own clothes, as if such work were the ultimate debasement. In one church he attended, he notes the presence of "wobbly bosomed black and yellow church matrons" and "skinny old maids" (Black Boy, 178), women he looks at but not with. More troubling, perhaps, is an incident involving a young black woman Wright observes as a white policeman slaps her on the buttocks; when Wright asks her how she can stand that kind of treatment, she replies that it does not matter. In response to her comment that he would have been a fool if he had done something about it, he tells her he would have been, meaning he would have been a fool to try to do something for her. She misses the point, according to the narrator, but we may wonder if Wright does not miss the point when he gives no consideration to why she might tolerate disrespectful treatment from a white man: doing anything else could have resulted in horrible consequences to her and to Wright. His attitude toward the white waitresses he works with in Chicago may also reveal a failure of empathy and imagination on his part: the reader should question why it is necessarily so bad that the "words of their souls were the syllables of popular songs" (Black Boy, 321). Equally disturbing is his reference to a woman he dislikes for regarding him as an Uncle Tom: "a huge, fat, black woman" (Black Boy, 432).

Unrecognized moulds about social class are everywhere in Black Boy. For example, although Wright despised the black middle class, he was evidently no fan of the black lower class either, for he was deeply concerned that his readers not think he could end up like his father, a "black peasant." He appears to believe that this would be a terrible fate, one to be evaded at any cost, and a kind of social abyss. A doubtful social view point also informs Wright's replies to the black families he sees when he works as an assistant to an insurance agent named Brother Nance:

"Many of the naive black families bought their insurance from us because they felt that they were connecting themselves with something that would make their children 'write'n speak lak dat pretty boy from Jackson' " (Black Boy, 160).

He later refers to such people as "walleyed yokels" ( $p$. 161), an unfortunate phrase that suggests Wright's social prejudices. He is intellectually aware that social classes are not natural entities because at one point in Black Boy he uses the phrase "the artificial status of race and class" ( $p .218)$, but this intellectual awareness about artificial social distinctions does not regulate his feelings about social class.

Black Boy is an account of racism, racial identity, and the effort of surviving as a young African-American man in the South. A unforgettable sketch of white racism and violence is offered by Richard Wright in Black Boy and illustrated that the creation of some social representations in his mind that help him to have a correct evaluation of whites' violent potential. His experience also teaches him many things about the way in which he should interact with them in the future so as to avoid being the victim of white violence in the American urban space: "I was learning rapidly how to watch white people, to observe their every move, every brief expression, how to interpret what was said and what left unsaid" (Black Boy, 183). However, we should point out that all Richard Wright's black characters are forced to adopt a humble and subservient attitude in order to avoid the aggressive manifestations of white racism. 


\section{References:-}

1. Cheney LV (July- August 1991). "A Conversation with Henry Louis Gates, Jr.” Humanities, 12: 4-10.

2. Gallantz, Michael, and Murray Bromberg. Richard Wright's Native Son \& Black Boy. Barron's Educational Series, 1985.

3. Gómez, J.D. (julio-diciembre de 2015). Socialism and identity in the life and works of Richard Wright. La palabra, (27), 33-43.

4. Meryem Ayan, "The cultural logic of racism in Richard Wright's Native Son," African Journal of History and Culture Vol. 3(9), pp. 135-139, December 2011

5. Page, Yolanda Williams, ed. Icons of African American Literature: The Black Literary World: The Black Literary World. ABC-CLIO, 2011.

6. Pallavi T. Ramteke, A Comparative Study of Human And Societal Values In The Novels of Aravindadiga, Richard Wright and Mulk Raj Anand, International Journal of Advanced System and Social Engineering Research, Vol3, Issue3, 2013, pp 68-77.

7. Spark Notes Editors. "SparkNote on Black Boy." SparkNotes.com. SparkNotes LLC. 2003. Web. 29 Aug. 2017.

8. Wright R (1940). Native Son. New York: Harper and Row.

9. Wright, Richard. Black Boy (American Hunger). London: Vintage Books, 2000 (first ed.: 1945).

10. Wright, Richard. Native Son. London: Vintage Books, 2000 (first ed.: 1940). 